\title{
ON THE DEFINITION OF THE HEALTHIEST BODY WEIGHT FOR CHILDREN AND ADULTS
}

\author{
Antonello LORENZINI \\ University of Bologna, Department of Biomedical and Neuromotor Sciences \\ Biochemistry Unit, Nutrition Research Center \\ Via Irnerio 48, 40126 Bologna, Italy \\ e-mail: antonello.lorenzini@unibo.it
}

\begin{abstract}
Ongoing changes in societies are driving an expanding fraction of the world's population towards a sedentary and overfed lifestyle. An overwhelming amount of data has linked increased body weight with an increased risk of acquiring a number of major diseases. Gerontologists, in order to extend the life span of laboratory animals, have used caloric restriction successfully for decades. This basic research on animals along with epidemiological data taken from vast human cohorts is cumulatively indicating that reducing one's body weight should be part of the strategy to increase health and life span while reducing pathologies. What is not a trivial matter is defining the correct weight for each individual. This mini review raises some discussion points regarding this important public health issue.
\end{abstract}

Keywords: longevity, life span, caloric restriction, dietary restriction, body weight, body mass index, mortality. 


\section{DEFINIRANJE NAJBOLJ ZDRAVE TELESNE TEŽE PRI OTROCIH IN ODRASLIH}

\section{IZVLE $\check{C} E K$}

Spremembe, ki potekajo v sodobnih družbah, vodijo vedno večji delež svetovnega prebivalstva k sedečemu življenjskemu slogu s preobilno prehrano. Velika količina podatkov povezuje povečano telesno težo s povečanim tveganjem za različna oboljenja. Gerontologi že desetletja uspešno uporabljajo metodo omejevanja vnosa kalorij pri laboratorijskih živalih, ki jim želijo podaljšati življenjsko dobo. Take osnovne raziskave na živalih, skupaj z epidemiološkimi podatki, pridobljenimi pri velikih človeških izvornih skupinah, kumulativno kažejo, da bi moralo biti zmanjšanje posameznikove telesne teže del strategije za povečanje zdravja in podaljšanje življenjske dobe, obenem pa bi moralo zmanjšati patologije. Kar ni zanemarljivo, je tudi opredelitev pravilne teže za vsakega posameznika. Ta kratek pregled torej sproža mnoge razprave v zvezi s pomembnimi dejstvi o javnem zdravju.

Ključne besede: dolgoživost, življenjska doba, omejevanje vnosa kalorij, omejevanje hrane, telesna teža, indeks telesne mase, smrtnost

\section{INTRODUCTION}

Urbanization and socio-economic changes in societies have driven a gradual change in an increasing fraction of the world's population towards a more sedentary and overfed lifestyle. One parameter clearly affected by this lifestyle change is body weight. An overwhelming amount of scientific data (for example, see Visscher \& Seidell, 2001) has linked increased body weight with an increased risk of acquiring a number of major diseases (cardiovascular, type 2 diabetes mellitus, cancer, osteoarthritis and others). This risk is higher when a person is classified as being obese or overweight early on in adult life and even worse during one's period of growth and development. The World Health Organization has indeed recently established a Commission on Ending Childhood Obesity (Commission on Ending Childhood Obesity, 2014). A biological explanation for the reason why childhood obesity may represent a higher public health risk than adult obesity can be found in the way adipose tissue develops. Fat tissue adopts two strategies to store more fat in the case of obesity: by increasing the number of adipocytes (hyperplasia) or by increasing the volume of every single adipocyte (hypertrophy). Several studies on rats have shown that the first strategy seems to be favoured during growth and development stages (see for example Oscai et al., 1974). A more recent study has also confirmed this in humans (Spalding et al., 2008). This last study has also shown that when significant weight loss is achieved through bariatric surgery in adulthood, a decrease in the average adipocyte volume, but not in adipocytes numbers 
Antonello LORENZINI: ON THE DEFINITION THE DEFINITION OF THE HEALTHIEST BODY WEIGHT FOR CHILDREN AND ADULTS, 103-112

is observed. We can interpret and summarize these results to suggest that childhood obesity favours hyperplasia while adult obesity favours hypertrophy. Fat tissue with higher cellularity is very likely more efficient in storing calories and consequently is a more obstinate adversary to weight loss treatments.

This mini-review is the transcription of my lecture at the $8^{\text {th }}$ International Conference A Child in Motion "Kinesiology - A Path of Health", held in Portorož, Slovenia in October 2014. In this paper I will discuss observations collected from the studies on caloric restriction and from epidemiological research that are dealing with the relation between mortality and body mass index (BMI). BMI is not the sole measure to estimate body fat; waist circumference, waist-to-hip ratio, plicometry and direct assessment of $\%$ body fat with techniques such as bioimpedentiometry are other ways of evaluating obesity that can also be combined. BMI is still commonly used both by doctors and in the public literature as a simple way to alert people regarding their weight. The World Health Organization is providing detailed BMI data for every country in a particular section on its web site that presents the "Global Database on Body Mass Index". I will try to prove that we lack a solid definition of healthy body weight and I will conclude with some considerations regarding future directions that should be considered by the science for healthy life style.

\section{CALORIC RESTRICTION AND LONGEVITY}

Correct nutrition and proper physical activity are considered the two pillars for a healthy life style.

Correct nutrition means an appropriate balance among macro- and micronutrients as well as an appropriate quantity of calories consumed to sustain an active life and at the same time to ensure the capacity to reach the genetically determined longevity potential of an individual. A recent large study has concluded that, at least in the case of mice, the best nutrition for a longer life span is the one mainly based on carbohydrates (Solon-Biet et al., 2014). There is a large amount of specialized literature on what is the best caloric intake for reaching the highest longevity. This literature provides ample experimental evidence that calorically restricting the diet in many experimental animals results in an extension of life span compared with the life span of animals with an unrestricted access to food (for a review see Matzko at al., 2009). A calorically restricted diet is a diet where the tested animals received a reduction in caloric intake usually a 30 or $40 \%$ of the unrestricted diet consumed by control animals. Caloric restriction, of course, in the vast majority of cases, reduces body weight and the percentage of body fat.

Also, higher physical activity levels have been reported as having a positive effect on life span. This has been observed by comparing two or more groups of animals with different activity levels (e. g. Holloszy \& Schechtman, 1993) or, for humans, when athletes' life spans were compared with the general population (e. g. Marijon et al., 2013). 
Antonello LORENZINI: ON THE DEFINITION THE DEFINITION OF THE HEALTHIEST BODY WEIGHT FOR CHILDREN AND ADULTS, 103-112

The American College of Sports Medicine and the American Heart Association have published their recommendations regarding the minimum amount of physical activity necessary to realize health-related improvements (Haskell et al., 2007). Additionally, it is interesting to consider that in a prospective analysis on older Americans, muscle mass relative to body height was associated inversely with all-cause mortality (Srikanthan \& Karlamangla, 2014).

From a gerontological point of view, if we look at how a survival curve of a cohort of laboratory rodents is modified by either nutritional or exercise interventions we can identify important differences. Caloric restriction increase both average and maximum life span while physical activity increases only average life span (Holloszy \& Schechtman, 1991). Gerontologists have interpreted this difference in the following way. Increased physical activity level creates a better "metabolic environment" lowering the risk of diseases (for a recent review on the biology of exercise, see Hawley et al., 2014). Caloric restriction, however, together with creating a better "metabolic environment" could also slow down the process of aging.

The phenomenon of caloric restriction has been observed experimentally for the first time in rats (McCay et al., 1935) and following this initial observation the experiment was performed in many other animal species, including dogs and cows. One important aspect to consider when analyzing caloric restriction experiments in rodents is that the restricted diet is often applied soon after weaning, i.e. during development. Consequently, not only the restricted animal are leaner (they have less body fat) but they are actually smaller (smaller dimensions with a reduction in fat free mass). Restricting calories during development can indeed slow down growth and result in smaller adults. It is interesting to note that there are several species where smaller size is associated with increased longevity: dogs (Greer et al., 2011), horses (Austad, 2010) and even humans. For humans, Samaras and colleagues have observed that between different ethnic groups smaller size is associated with longer life span and that lighter and shorter baseball players are usually longer-lived (Samaras et al., 2002, 2003). The laboratory animals more phylogenetically related to human and, actually, the caloric restriction has been tested in rhesus monkeys. Unfortunately, data from these experiments are unclear. Two laboratories have concomitantly performed two large investigations with different experimental protocols obtaining different results (Colman et al., 2014; Mattison et al., 2012). Translating caloric restriction results from animal studies to human studies is not straightforward. We will come back to this issue in the conclusion of this mini review.

\section{BODY MASS INDEX AND MORTALITY}

Caloric restriction experiments have established a solid relation between the energetic balance of an organism and its life span. In comparison, few are the experiments in animals where scientists have tried to investigate the relationship between the percentage of body fat and longevity. This is due to technical difficulties in measuring the 
Antonello LORENZINI: ON THE DEFINITION THE DEFINITION OF THE HEALTHIEST BODY WEIGHT FOR CHILDREN AND ADULTS, 103-112

percentage of body fat in animals and also due to the absence of something equivalent to what is routinely used for humans: body mass index (BMI). The BMI, initially proposed by Adolphe Quetelet (Eknoyan, 2007), is defined as the individual's body mass divided by the square of his height, with the value universally being given in $\mathrm{kg} / \mathrm{m}^{2}$. It is a simple and easy-to-measure approach to estimate the percentage of body fat. Because of large anthropometric differences among individuals, however, BMI is quite imprecise in measuring the percentage of body fat.

In epidemiology, large data collections are used to study the relationship between all-cause mortality and anthropometric values. In the majority of these studies it is observable a U-shaped relationship between the two values: very low BMI values (extreme leanness) are associated with increase mortality and very high BMI values (extreme obesity) also are associated with increased mortality.

Naturally, many of these studies are based on anthropometric values measured few times or even only one time during the life span of an individual. What is important for the present discussion is the persistence of obesity or overweight during the entire life span, which until now has not been easy to monitor in large cohorts. Some studies, for example, have observed that the presence of overweight in childhood and adolescence increases the risk of being obese in adulthood, with the major risk being represented by overweight in later adolescence (Must, 1996; Guo et al., 1994; Ferraro et al., 2003).

Going back to the BMI - mortality relationship, it is clear that BMI value at the lowest inflection point in this curve would indicate the optimal weight range for each individual, and we would expect this point to lay somewhere in the "normal weight" of the BMI category (from 18.5 to $25 \mathrm{~kg} / \mathrm{m}^{2}$ ). A recent meta-analysis by Flegal and colleagues that has analysed eight different large epidemiological studies, however, challenges this expectation (Flegal et al., 2014). These studies have calculated hazard ration using more specific BMI categories than the ones proposed by the World Health Organization and the American National Heart, Lung, and Blood Institute. The standard categories are the following: Underweight, Normal Weight, Overweight and Obesity (see Table 1 for BMI cut-offs). In the study by Flegal and colleagues, the categories used are the following: Underweight, Low-, Mid-, and High-Normal Weight, Low and High Overweight, and Obesity Grade 1 (see Table 1 for BMI cut-offs). Simply by the name chosen for the standard weight categories one would expect that the "Normal Weight" categories should represent a "healthier" state than the "overweight" categories. Instead, from the data of the meta-analysis the two categories with the lowest hazard ratio are the "High - Normal Weight" and the "Low Overweight". This is true for the entire male cohort, for the never-smokers male cohort and for the entire female cohort. Instead, for the never smoker woman cohort, the two categories with the lowest hazard ratio are "Mid- Normal Weight" and "High- Normal Weight". The question is: "are these, after all, respectively for gender and smoking status, the healthiest categories?" Naturally, these data are also underlining the importance of life style habits. The difference observed in female between the never-smokers and the entire cohort, for example, underlines the importance of avoiding unhealthy behaviours. One could speculate that never smokers are more prone to make other life style choices capable 
Antonello LORENZINI: ON THE DEFINITION THE DEFINITION OF THE HEALTHIEST BODY WEIGHT FOR CHILDREN AND ADULTS, $103-112$

of carry additional but independent health benefits: e.g. healthier diet composition and more physical activity (see respectively Solon-Biet et al., 2014; Kokkinos et al., 2008).

\section{CONCLUSIONS}

If we try to summarize and translate in simple "take-home" messages the scientific evidences discussed in the two preceding paragraphs, we could say:

- Caloric restriction experiments in animals are suggesting that a possible way to increase human life span is the adoption of a diet with a substantial reduction in energy content from the regular diet where each individual eats as much as he or she desires.

- A recent epidemiological analysis is showing that the lowest mortality is found not with a BMI value in the "Mid- Normal Weight" range but instead with a BMI more at the boundary between the "High- Normal Weight" and "Low Overweight" categories.

Is it possible to reconcile these two statements? Although interesting analyses have been published (e.g. Fontana \& Hu, 2014; Bozorgmanesh et al., 2014) we, at present, probably lack enough evidence that could help us solve this conundrum. For caloric restriction, for example, it is important to understand if ad libitum (freely) fed animals are indeed in a normal state (e.g., for mice see Austad \& Kristan, 2003). Can these unrestricted control animals be considered representative of the majority of human population, which is, of course, usually free to eat as much as desired? To answer this question we will need to pursue more investigations on fatness of control animals and on its role on life span. Laboratory animals, especially rodents which have been largely used in caloric restriction experiments, are routinely keep in constant presence of food and water similarly to what we do for some caged house pets, for example birds or hamsters. Some have argued that this condition is unhealthy and "obesogenic" and should not be used to represent the majority of humans (e.g. Martin et al., 2010).

$\mathrm{BMI}$ is a rather crude estimate for the percentage of body fat and is influenced, aside from energy intake, by factors unrelated to diet: physical activity level, gender, age, health status, smoking status, etc. The classical BMI categories seem to be too broad to distinguish sub-populations with different health risks. There is a need for additional studies and, ideally, for a consensus statement by the experts that will redefine the BMI cut-offs. BMI categories will also need to be specific for sex, age and ethnic groups. In fact, discussions on these points are ongoing (e.g. Friedman, 2014; Stevens, 2014).

As mentioned above, caloric restriction experiments on rhesus monkeys have given mixed answers (Colman et al., 2014; Mattison et al., 2012). In one study, the calorically restricted monkey had a clear life span benefit while in the other there was no statistically significant difference. One possible explanation can be found in how the restricted diet was planned. The study that did show a benefit was comparing ad libitum monkeys with monkeys receiving a $30 \%$ restriction of their ad libitum consumption. The study 
Antonello LORENZINI: ON THE DEFINITION THE DEFINITION OF THE HEALTHIEST BODY WEIGHT FOR CHILDREN AND ADULTS, $103-112$

that did not show the caloric restriction benefit used, as controls, monkeys that were partially restricted (around a $10 \%$ restriction in comparison to ad libitum feeding) to avoid adult obesity. The experimental group of monkeys, in addition, received a 30\% reduction from this obesity-preventing diet. The differences between the two studies included also a difference in diet composition but we can already predict that the different restriction protocols could very well have a repercussion on body composition, and they actually did. A deeper focus on body composition is necessary both for the basic science of caloric restriction and for large epidemiological studies that will help to clarify how to translate these mixed results to human-based situations. For a more in-depth discussion on these studies, see also Lorenzini, 2014.

Our society is fascinated by tall persons. Therefore, parents are usually happy if their child or adolescent is in the upper percentiles regarding stature. When correct nutrition is provided, the growth and development should unfold to their full potential. On average, being taller also means being heavier but parents of tall children should not worry unless the paediatrician says so. From the evidence reviewed so far, on the other end, we can at least conclude by reassuring the parents of children or adolescents that are in the lower half of the percentiles for weight or stature, or both, in comparison to their peers. Unless the child is at a percentile, so low that the chance for serious pathologies or for dwarfism must be considered, the parents should not worry. They should not be concerned about how to teach them to eat all the food in their dish, about how to modify their diet to improve their appetite, or about what the paediatrician may prescribe to improve their growth. These parents should instead be invited to consider that a lighter and a shorter child would have smaller chances to become an obese adult as well as more chances to have a longer and healthier life.

Table 1: Standard BMI categories and categories used in the study by Flegal et al., 2014.

\begin{tabular}{|c|c|}
\hline Standard BMI categories & Categories used in the study by Flegal et al., 2014 \\
\hline less than 18.5: Underweight & $15.0-18.4$ Underweight \\
\hline \multirow{2}{*}{$18.5-24.9:$ Normal Weight } & $18.5-19.9$ Low- Normal Weight \\
\cline { 2 - 2 } & $20.0-22.4$ Mid- Normal Weight \\
\cline { 2 - 2 } & $22.5-24.9$ High- Normal Weight \\
\hline \multirow{2}{*}{$25.0-29.9:$ Overweight } & $25.0-27.4$ Low Overweight \\
\cline { 2 - 2 } & $27.5-29.9$ High Overweight \\
\hline 30.0 or more: Obesity & $30.0-34.9$ Obesity Grade 1 \\
\hline
\end{tabular}


Antonello LORENZINI: ON THE DEFINITION THE DEFINITION OF THE HEALTHIEST BODY WEIGHT FOR CHILDREN AND ADULTS, 103-112

\section{REFERENCES}

Austad, S. N., Kristan, D. M. (2003). Are mice calorically restricted in nature? Aging Cell, 2(4), 201-7.

Austad, S. N. (2010). Capter 2, Animal size, Mataolic rate, and survival, among and within species (p. 27). In Wolf, E. (Ed.), The comparative Biology of Aging. Springer.

Bozorgmanesh, M., Arshi, B., Sheikholeslami, F., Azizi, F., \& Hadaegh, F. (2014). No Obesity Paradox-BMI Incapable of Adequately Capturing the Relation of Obesity with All-Cause Mortality: An Inception Diabetes Cohort Study. International Journal of Endocrinology, 282089. doi: 10.1155/2014/282089. Epub 2014 Aug 7.

Colman, R. J., Beasley, T. M., Kemnitz, J. W., Johnson, S. C., Weindruch, R., \& Anderson, R. M. (2014). Caloric restriction reduces age-related and all-cause mortality in rhesus monkeys. Nature Communication, 5, 3557.

Commission on Ending Childhood Obesity (2104). Report of the First Meeting of the Ad hoc Working Group on Science and Evidence for Ending Childhood Obesity. 18-20 June 2014, Geneva, Switzerland. Available at the WHO web site.

Eknoyan, G. (2007). Adolphe Quetelet (1796-1874) - the average man and indices of obesity. Nephrology Dialysis Transplantation, 23(1), 47-51.

Ferraro, K. F., Thorpe, R. J. Jr., \& Wilkinson, J. A. (2003) The life course of severe obesity: does childhood overweight matter? The Journal of Gerontology Series B: Psychological Sciences and Social Scienses, 58(2), S110-9.

Flegal, K. M., Kit, B. K., \& Graubard, B. I. (2014). Body mass index categories in observational studies of weight and risk of death. American Journal of Epidemiology, 180(3), 288-96.

Fontana, L., \& Hu, F. B. (2014). Optimal body weight for health and longevity: bridging basic, clinical, and population research. Aging Cell, 13(3), 391-400. doi:10.1111/acel.12207.

Friedman, G. D. (2014). Body mass index and risk of death. American Journal of Epidemiology, 180(3), 233-4.

Greer, K. A., Hughes, L. M., \& Masternak, M. M. (2011). Connecting serum IGF-1, body size, and age in the domestic dog. Age (Dordr), 33(3), 475-83.

Guo, S., Roche, A., Chumlea, W., Gardner, J., \& Siervogel, R. (1994). The predictive value of childhood body mass index values for overweight at age $35 \mathrm{y}$. American Journal of Clinical Nutrition, 59, 810-819.

Haskell, W. L., Lee, I. M., Pate, R. R., Powell, K. E., Blair, S. N., Franklin, B. A., Macera, C. A., Heath, G. W., Thompson, P. D., Bauman, A.; American College of Sports Medicine; American Heart Association (2007). Physical activity and public health: updated recommendation for adults from the American College of Sports Medicine and the American Heart Association. Circulation, 116(9), 108193. Epub 2007 Aug 1.

Hawley, J. A., Hargreaves, M., Joyner, M. J., \& Zierath, J. R. (2014). Integrative Biology of Exercise. Cell, 159(4), 738-749. Review. 
Antonello LORENZINI: ON THE DEFINITION THE DEFINITION OF THE HEALTHIEST BODY WEIGHT FOR CHILDREN AND ADULTS, 103-112

Holloszy, J. O., \& Schechtman, K. B. (1991). Interactions between exercise and food restriction: effects on longevity of male rats. Journal of Applied Physiology, 70, $1529-1535$.

Kokkinos, P., Myers, J., Kokkinos, J. P., Pittaras, A., Narayan, P., Manolis, A., Karasik, P., Greenberg, M., Papademetriou, V., \& Singh, S. (2008). Exercise capacity and mortality in black and white men. Circulation, 117(5), 614-22.

Lorenzini, A. (2014). How Much Should We Weigh for a Long and Healthy Life Span? The Need to Reconcile Caloric Restriction versus Longevity with Body Mass Index versus Mortality Data. Front Endocrinol (Lausanne). 5:121. doi: 10.3389/fendo.2014.00121.

Marijon, E., Tafflet, M., Antero-Jacquemin, J., El Helou, N., Berthelot, G., Celermajer, D. S., Bougouin, W., Combes, N., Hermine, O., Empana, J. P., Rey, G., Toussaint, J. F., \& Jouven, X. (2013). Mortality of French participants in the Tour de France (1947-2012). European Heart Journal, 34(40), 3145-50.

Martin, B., Sunggoan, J., Maudsley, S., \& Mattson, M. P. (2010). 'Control' laboratory rodents are metabolically morbid: why it matters. Proceedings of the National Academy of Sciences, 107, 6127-6133.

Mattison, J. A., Roth, G. S., Beasley, T. M., Tilmont, E. M., Handy, A. M., Herbert, R. L., Longo, D. L., Allison, D. B., Young, J. E., Bryant, M., Barnard, D., Ward, W. F., Qi, W., Ingram, D. K., \& de Cabo, R. (2012). Impact of caloric restriction on health and survival in rhesus monkeys from the NIA study. Nature, 489, 318-321.

Matzko, M., McCarter, R. J., Masoro, E. J. (2009). Chapter 6, Global Food Restriction (p. 91) in Life-Span Extension: Single-Cell Organisms to Man By Sell, Lorenzini, and Brown-Borg. Springer, Jul 27, 2009

McCay, C. M., Crowell, M. F., \& Maynard, L. A. (1935). The Effect of Retarded Growth Upon the Length of Life Span and Upon the Ultimate Body Size: One Figure, Journal of Nutrition, 10, 63-79.

Must, A. (1996). Morbidity and mortality associated with elevated body weight in children and adolescents. American Journal of Clinical Nutrition, 63, 445S-447S.

Oscai, L.B., Babirak, S. P., Dubach, F. B., McGarr, J. A., \& Spirakis, C. N. (1974). Exercise or food restriction: effect on adipose tissue cellularity. American Journal of Physiology, 227, 901-904.

Samaras, T. T., Elrick, H., \& Storms, L. H. (2003). Is height related to longevity? Life Sciences, 72(16), 1781-802.

Samaras, T. T., Storms, L. H., \& Elrick, H. (2002). Longevity, mortality and body weight. Ageing Research Reviews, 1, 673-691.

Solon-Biet, S. M., McMahon, A. C., Ballard, J. W., Ruohonen, K., Wu, L. E., Cogger, V. C., Warren, A., Huang, X., Pichaud, N., Melvin, R. G., Gokarn, R., Khalil, M8, Turner, N., Cooney, G. J., Sinclair, D. A., Raubenheimer, D., Le Couteur, D. G., \& Simpson, S. J. (2014). The ratio of macronutrients, not caloric intake, dictates cardiometabolic health, aging, and longevity in ad libitum-fed mice. Cell Metabolism, 19(3), 418-30.

Spalding, K. L., Arner, E., Westermark, P. O., Bernard, S., Buchholz, B. A., Bergmann, O., Blomqvist, L., Hoffstedt, J., Näslund, E., Britton, T., Concha, H., 
Antonello LORENZINI: ON THE DEFINITION THE DEFINITION OF THE HEALTHIEST BODY WEIGHT FOR CHILDREN AND ADULTS, 103-112

Hassan, M., Rydén, M., Frisén, J., \& Arner, P. (2008) Dynamics of fat cell turnover in humans. Nature, 453(7196), 783-7.

Srikanthan, P., Karlamangla, A. S. (2014). Muscle mass index as a predictor of longevity in older adults. American Journal of Medicine, 127(6), 547-53. doi: 10.1016/j.amjmed.2014.02.007. Epub 2014 Feb 18.

Stevens, J. (2014). Re: "Body Mass Index Categories in Observational Studies of WEight and Risk of Death" and "Editorial: Body Mass Index and Risk of Death". American Journal of Epidemiology, 1, 180(11), 1128-9. doi: 10.1093/aje/kwu299.

Visscher, T. L. S., \& Seidell, J. C. (2001). The Public health impact of obesity. Annual Review of Public Health, 22, 355-375. 